\title{
Human Dimensions of Forest Disturbance by Insects: An International Synthesis
}

\author{
Courtney G. Flint $\cdot$ Bonnie McFarlane • \\ Martin Müller
}

Received: 13 April 2008/Accepted: 27 July 2008/Published online: 5 September 2008

(C) Springer Science+Business Media, LLC 2008

\begin{abstract}
Ecological disturbances of forests by insects have a complex array of associated human dimensions presenting complications for natural resource decision making and relationships between stakeholders and managers. This article discusses the human context of forest disturbances by insects by reviewing four cases of bark beetle forest disturbance from British Columbia in Canada, Bavarian Forest National Park in Germany, the Kenai Peninsula in Alaska, and the north central region of Colorado. Findings and lessons learned from these studies are outlined along with their implications for managing forest disturbances by insects in general. Conclusions focus on the need to assess the broad array of impacts and risks perceived by local residents and the capacity for local action and involvement in managing forest disturbances. Communication and interaction between resource managers and local stakeholders can facilitate the identification of management priorities and potentially reduce some of the risks associated with forest disturbances by insects.
\end{abstract}

C. G. Flint $(\bowtie)$

Department of Natural Resources and Environmental Sciences, University of Illinois at Urbana-Champaign, S510 Turner Hall, 1102 South Goodwin Avenue, Urbana, IL 61801, USA

e-mail: cflint@illinois.edu; cflint@uiuc.edu

URL: http://communitynatres.nres.uiuc.edu

\section{B. McFarlane}

Natural Resources Canada, Canadian Forest Service, 5320-122 Street, Edmonton, AB, Canada T6H 3S5

e-mail: bmcfarla@nrcan.gc.ca

\section{Müller}

Department of Human Geography, J. W. Goethe-Universität Frankfurt am Main, Robert-Mayer-Street 8, 60325 Frankfurt, Germany

e-mail: martin.mueller@em.uni-frankfurt.de
Keywords Bark beetles - Community response . Forest disturbance $\cdot$ Forest management . Human dimensions

\section{Introduction}

Ecological disturbances are often multiple, interacting events or cascading sets of disturbances that together change landscapes to varying degrees (Dale and others 2001; Rogers 1996). Disturbances can be abiotic (e.g., drought, fire, wind, or geomorphological events), biotic (e.g., insects, disease, or grazing), or directly caused by humans (e.g., logging, burning, or mining) (Rogers 1996). Forest disturbance by insects, for example, may be exacerbated by drought and wind events and may lead to increased fire activity and altered susceptibility to disease (Oliver and Larson 1996).

Each type of ecological disturbance has its own set of societal ramifications. Whether or not, and how, to incorporate natural disturbance regimes in natural resource management is often complicated by competing values and perceptions from within the human dimensions of changing ecosystems. Fire disturbances intersect with a number of areas, including emergency management, public and property safety, aesthetic and scenic values, economic considerations, and water management. Insect and disease disturbances may involve some of the same concerns as fire, but are also likely to affect timber quality, landscape change, and forest management needs across different temporal and spatial scales. Ecosystem disturbances expose vulnerabilities and challenge relationships, trust, and confidence between stakeholders and resource managers. On the other hand, such disturbances may catalyze collective action across diverse constituencies, building new relationships. 
Given the common and complex interactions among various disturbance agents, such as fire and insects, it is equally likely that complex and conflicting human dimensions exist as well. Landscape ecologists and others involved in research related to ecological disturbances often refer to heterogeneity across changing eco-landscapes (Pickett and Cadenasso 1995; Oliver and Larson 1996; Gardner and others 2001). It is all too often ignored that society, with its multiple jurisdictions, stakeholders, values, interests, institutions, capacities, and vulnerabilities, is just as heterogeneous, if not more so, than ecological systems.

The shift to an ecosystem management framework for resource management in recent years has brought about a paradigm shift in thinking about the role of ecological disturbance in natural resource management (Rogers 1996). Previously, managers approached disturbances as negative events with problematic impacts on ecology and natural resources. Tied to an emphasis on ecosystem stability and equilibrium, this perspective has faded and been replaced by an acceptance of nonequilibrium dynamics and flux in natural resource management (Zimmerer 2000). Contemporary ecological and management viewpoints tend to emphasize disturbances as possibly complementary rather than only deleterious to forest functions (Rogers 1996). According to Rogers (1996, p. 13), preserving natural disturbance regimes has come to be seen as an essential part of promoting "healthy, dynamic ecosystems." There is a decreasing emphasis on suppressing disturbances as part of natural resource management of ecosystems. This shift has meant that from an ecological point of view, natural disturbances are seen as more value-neutral.

On the other hand, from a societal standpoint, ecological changes are frequently seen as undesirable, yet more difficult to avoid particularly in areas where society and the physical environment are strongly interacting (Drever and others 2006). In other words, from a human dimensions standpoint, ecological or natural disturbances are rarely seen as value-neutral events. More often, disturbances have a complex array of value-laden factors that may conflict with one another, leading to policy and societal crises (Drever and others 2006). Whether or not and how natural resource managers incorporate natural disturbances in ecosystem management decisions are not simple questions. Resource managers and decision makers must also contend with complex human dimensions and competing values, perceptions, and actions at multiple jurisdictional and societal scales, which intersect with changing landscapes in dynamic ways.

One of the reasons for increasing complexity in the human dimensions of ecological or forest disturbance is the way in which people socially construct or view ecological processes and risks through varying lenses influenced by culture, physical settings, political processes, sociodemographic circumstances, and societal interactions (Kasperson and others 1988; Greider and Garkovich 1994; Irwin 2001; Flint and Luloff 2005). The possibility, indeed likelihood, of subjective and emotional interpretations of physical processes and landscape change by local and distant stakeholders complicates an already complex management situation. The old saying in sociology, "If men define situations as real, they are real in their consequences" (Thomas 1928, p. 571-572) is especially appropriate in the case of human response to forest disturbances. Public and local community perceptions and responses may or may not mirror that of resource managers. People are likely to develop attitudes and take action based upon what they perceive to threaten their individual and community wellbeing (Tilly 1973) with important consequences for resource management. Given that multiple perspectives are common within communities, the tangled web of human reactions is likely to require patience and skill for interpretation and incorporation into management decisions. The transfer of information necessary to promote sound decision making in the face of ecological disturbances runs in multiple directions, not only from resource managers to citizenry.

The human dimensions of forest disturbances by insects are relatively understudied. Assessments of forest health and forest disturbances often clearly articulate ecological and biophysical parameters but only speculate about societal impacts and implications (Ross and others 2001). Literature in the human dimensions of forest disturbances to date has focused on particular sectors, such as economic impacts (Rosenburger and Smith 1997) or specific scales of human reaction, such as private landowners (Molnar and others 2007), local residents (McFarlane and others 2006), tourists (McFarlane and Watson 2008; Müller and others 2008), or communities (Flint 2006; Flint and Haynes 2006; Flint and Luloff 2007; Parkins and MacKendrick 2007). Understanding perceptions, experiences, and actions of local residents and communities are critical to managing rapidly changing forest ecosystems. This synthesis article seeks to further the understanding of human and community dimensions of forest disturbance by insects by bringing together four case studies from British Columbia in Canada, Germany, and Colorado and Alaska in the United States. This article emphasizes lessons learned from these cases and their implications for managing human dimensions of forest disturbances by insects (summarized in Table 1).

\section{Case Studies}

Mountain Pine Beetles in Western Canada

The mountain pine beetle (Dendroctonus ponderosae) is endemic to lodgepole pine (Pinus contorta) forests of 


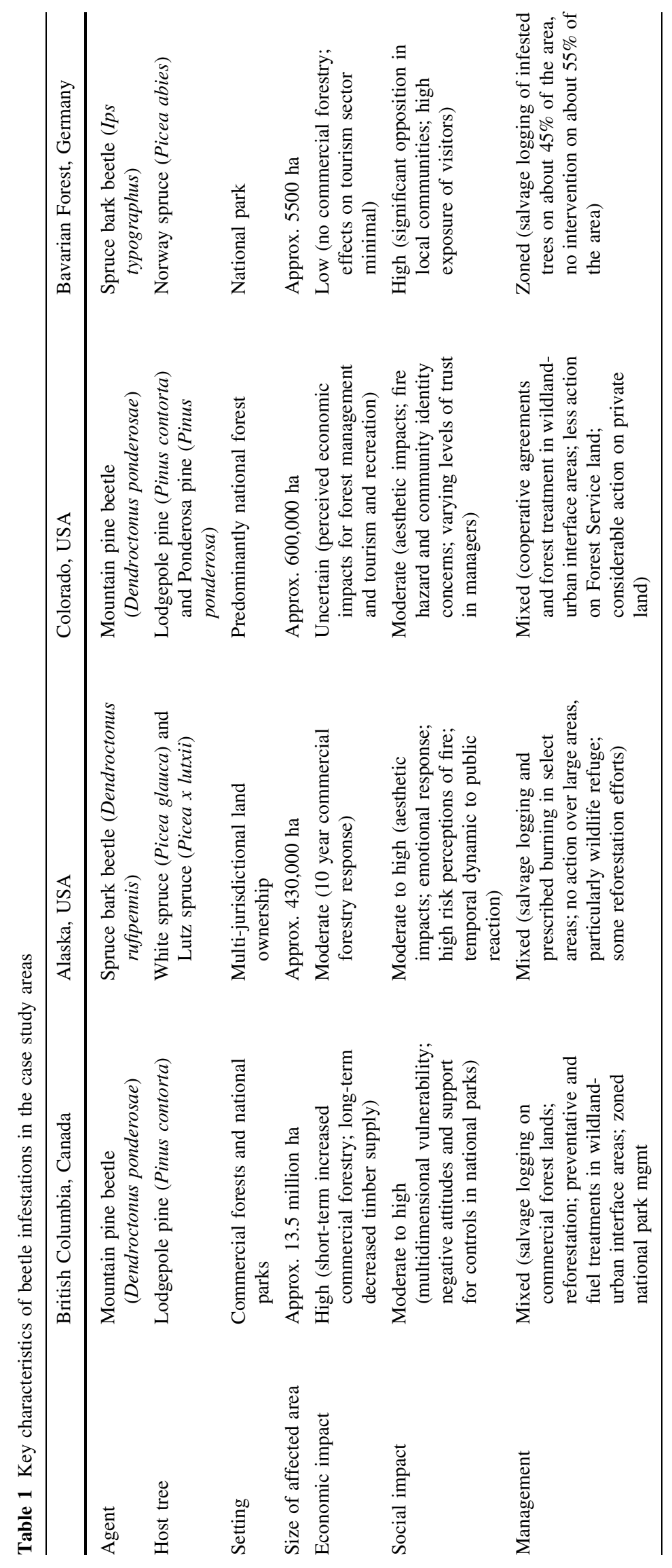


western Canada. However, recently the province of British Columbia has experienced the most extensive outbreak of the insect ever recorded in North America (Taylor and Carroll 2004). Since the 1990s the outbreak has increased exponentially, infesting over 13 million hectares of primarily public land by 2007 (British Columbia Ministry of Forests and Range 2007). The British Columbia outbreak is expected to largely subside by the year 2015 but its impacts will continue for decades. The main contributors to the outbreak are climate (hot, dry summers and above normal winter temperatures) and an abundance of mature lodgepole pine resulting from decades of fire suppression. Preventing the spread of small endemic populations through preventive forest management is the best control method. Once the beetle reaches the outbreak stage, little can be done to prevent its spread.

The forest sector has long been a major contributor to the economy of British Columbia. Although its importance has declined somewhat as the province's economy has diversified, it accounts for $7 \%$ of employment and $15 \%$ of all economic activity in the province (British Columbia Ministry of Forests and Range 2006). Many rural communities depend on the forest sector for their economic and social well-being. The mountain pine beetle (MPB) infestation is having a tremendous impact on timber supply with beetle-killed volume of about 530 million $\mathrm{m}^{3}$. The amount of timber allocated for harvesting has been increased to above sustainable levels in order to salvage dead timber from beetle infested forests but, as timber supply decreases, harvest levels are also expected to decline. This will likely result in an economic boom for communities in the shortterm, but a decline in economic activity as timber shortages occur in the long-term. In addition to impacts on timber, non-timber values of the forest are also affected by the infestation, especially in protected areas. These include, for example, impacts on recreational experiences by affecting the aesthetics of an area and the closure of trails for safety concerns resulting in a loss of income from tourism.

Impacts are unlikely to be uniform across the infested area. Some areas have higher biophysical risk than others because of the predominance of lodgepole pine. In addition, communities in the infested area have different levels of economic dependence on the forest industry and thus, will differ in the impact of the timber supply and some communities may be better adapted to absorb a shock to the forest sector. Therefore, strategies that might work for one community might not work for another.

The varied temporal and spatial impact of the infestation and the need to develop strategies based on individual community vulnerability was highlighted through studies of economic impacts and the ability of communities to adapt. To assess regional variability of local economies to changes in timber supply, Patriquin and others (2007) developed a regional economic impact model. Deviating from typical economic impact assessments, which use a large scale of analysis (e.g., provincial), they developed a computable general equilibrium (CGE) model and examined both the short-term and longer-term changes in timber supply of five regions of British Columbia. Simulating changes in forestry sector exports, they showed that the response varied by each region with some regions better able to absorb the shock of a future timber supply shortage. In the short term, they predicted that the regional economies will benefit from an increased timber supply as a result of salvage logging. However, the longer-term economic impacts in the regions are negative as the timber supply decreases. Regions with a more diverse industrial mix and less dependence on the forest sector were predicted to be the least vulnerable to changes in timber supply.

To further the understanding of community's ability to adapt to the infestation, Parkins and MacKendrick (2007) developed a community vulnerability framework to examine the potential impacts of the MPB infestation on four communities located in the area identified as a priority for beetle management by the provincial government. Drawing upon secondary (e.g., provincial forest and census data) and primary data sources (focus groups and mail surveys), Parkins and MacKendrick developed a vulnerability framework that included physical, social, political, and economic dimensions. The community-level framework showed variation in vulnerability among communities that would not be captured with provincial or national level assessments. The multidimensional nature of the framework provided an indication of the dimensions that might pose the greatest vulnerability for a community. For example, some communities had a high level of physical risk but this was tempered by political and economic factors whereas residents in communities with relatively low physical risk perceived the impacts to be high suggesting that adaptive strategies should not be limited to communities in the immediate geographic area of the infestation. The study also revealed that residents had only moderate levels of satisfaction with MPB management and low levels of trust in government institutions to manage impacts and risks associated with the infestation.

These studies highlight the complexity of the community impacts of natural disturbance and the importance of a holistic approach to vulnerability that extends beyond the traditional approach of biophysical risk and economic impacts to developing methods and frameworks that delineate social, political, and institutional capacities at the community level. Impacts and capacity to adapt will vary among communities and policies and programs should focus resources and target adaptive strategies for each community. 
Studies aimed at assessing the public's subjective evaluation of MPB impacts on non-timber values revealed strong reactions to beetle outbreaks in national parks. National parks management priorities emphasize the maintenance of ecological integrity or conditions characteristic of a natural region (Parks Canada 2003). MPB is endemic to the parks and the outbreak raised the question as to whether or not the beetles should be allowed to run their course naturally as part of the ecological integrity mandate. McFarlane and others (2006) found that residents living in or near national parks had negative attitudes towards the presence of beetles in the parks. For example, the beetles were viewed as a threat to biodiversity, an ecological disaster, and resulting in economic loss to tourism. Allowing the outbreak to run its course without intervention was not an acceptable management option for local residents. However, residents preferred treating infested areas rather than proactively using prescribed fire or thinning to reduce susceptible host trees in areas not affected by the beetle. Although the beetle was an important issue for residents, they were not very well-informed about the beetle, lacking a basic understanding of MPB ecology, its potential beneficial role in ecosystems, and impacts on the environment. The study highlighted the need for communication strategies aimed at fostering deliberations and an informed response to policy and management options and that are targeted to address the concerns of specific communities.

Visitors to the national parks also had a negative assessment of the MPB. They rated the beetles as posing greater risks to ecosystems than anthropogenic hazards (e.g. industrial activity and tourism development) and other natural disturbance agents (McFarlane and Watson 2008). Ecological and visitor impacts were perceived as negative and unacceptable and visitors supported controlling MPB populations in the parks. Support for controlling beetle populations was influenced by perceived risk to ecosystems rather than perceived risk to the visitor experience. The unprecedented extent of the outbreak and publicity by the media, governments, and the forest industry that characterizes the beetle infestation as catastrophic may be influencing perceptions of the MPB in protected areas.

The analysis of public perceptions of MPB in protected areas revealed a disconnection between the management agency's ecological integrity objective to allow natural disturbance and limits to public acceptance of MPB. There may be limits on the social acceptability of managing the beetle based on ecological integrity principles especially if the disturbance is perceived to pose a threat to ecosystems, biodiversity, and local economies and when the issue is of high personal importance. Clearly, local residents and visitors did not view MPB as an agent of ecosystem renewal. Rather, it was viewed as a threat to ecosystems, and they supported controlling MPB populations.

Spruce Beetles in the Kenai Peninsula in Alaska

Spruce bark beetles (Dendroctonus rufipennis) dramatically changed the forests of Alaska's Kenai Peninsula over the last two decades. The massive loss of white spruce (Picea glauca) and Lutz spruce (Picea x lutxii) across more than 400,000 hectares altered forest ecology and seriously affected the lives of people living in communities across the region. Drivers of this forest disturbance include climate change (particularly warmer winters and warmer, drier summers), host suitability, and host susceptibility (Werner and others 2006; Berg and others 2006). The fact that the Kenai Peninsula's forests were relatively evenaged, naturally homogeneous stands of spruce meant that landscape change from spruce bark beetle activity was quite dramatic, particularly across the Lower Peninsula.

Kenai Peninsula communities are forest dependent in as much as forests are critical to the amenity attributes, scenic integrity, fish and wildlife habitat, and timber harvesting activities across the region. Timber harvesting on the Peninsula was not a significant industry prior to the bark beetle impact but peaked during a ten year boom-bust response to salvage disturbed forests. Beetle-killed timber was cut, chipped, and shipped for pulp and paper in Canada and East Asia until the chip facility in Homer shut down in 2004 due to declining timber quality in beetle-killed spruce. Native Associations, focused on economic activity for tribal communities, were engaged in timber harvesting to varying degrees. The complex mosaic of land ownership on the Kenai Peninsula complicated forest management of the bark beetle disturbance. The Chugach National Forest was the dominant management agency in the mountainous region around Cooper Landing and Moose Pass, Alaska. In the Lower Peninsula, ownership was divided among the US Fish and Wildlife Service, the State of Alaska, the Kenai Peninsula Borough, Native Associations, municipalities, and private landowners.

Research on the human dimensions of this forest disturbance in early years of the disturbance assessed public attitudes to forest management strategies, finding widespread concern about impacts of beetle activity on the scenic integrity of Kenai Peninsula forests (Daniel and others 1991; Kruse and Pelz 1991). More recent research focused on assessing attitudes and perceptions of Kenai Peninsula residents and variations across communities regarding spruce beetle impacts, forest risks and hazards, forest management, and factors influencing community action in response to forest risks following spruce beetle activity (Flint 2007; Flint and Luloff 2007; Flint 2006; Flint and Haynes 2006). 
Kenai Peninsula communities varied substantially in how they responded to the spruce bark beetle experience. This forest disturbance was often represented as a fire management concern from forest management agencies. However, public perception research found a wide array of perceived impacts including increased fire hazard, falling trees, declining watershed quality and wildlife habitat, economic fluctuations, increased ecological awareness, landscape change, and emotional loss (Flint 2006; Flint and Haynes 2006). These perceived impacts were rather community specific. In some communities, increased timber harvesting brought short-term, positive economic change in the wake of the spruce beetle outbreak. In other communities, the loss of a living spruce forest profoundly affected quality of life, and led to community conflict, increased risk perception, and economic challenges (Flint 2006).

Forest related risks were keenly felt by Kenai Peninsula residents. Two distinct types of risk perception were: (1) immediate threats to safety and property from fire and falling trees; and (2) broader risks to ecological and community well-being, including watersheds, wildlife, privacy, and local economies (Flint and Haynes 2006; Flint and Luloff 2007). Communities at different stages in the spruce beetle outbreak revealed variations in perceived impacts and risks. Local response by residents was clearly dynamic, waxing and waning over time as the beetle impacts intensified and then declined. Early reactions were emotional as anger and frustration were followed by grief and sadness over the loss of what residents considered their forests and their trees. At the peak of the beetle outbreak, the experience of losing nearly $90 \%$ of trees became a strong element of local consciousness. In many communities, forests were a critical aspect of local identity and quality of life and threats to their existence profoundly affected local residents. However, with the passage of time and visible signs of re-growth underneath the grey, dead stands, public reactions mellowed (Flint 2007). Community reactions followed the uneven beetle disturbance patterns over two decades, meaning that they did not respond evenly over time and space.

The diverse array of impacts and risks from the spruce beetle outbreak perceived in Kenai Peninsula communities presented obstacles for forest management in the context of changing forest conditions. The relationship between local communities and land managers was considerably strained. Forest managers were frustrated by the mix of community reactions and the vocal opposition from residents from both environmental and resource utilization perspectives. Fewer than $40 \%$ of community survey respondents expressed satisfaction with the way borough, state, and federal land managers were handling forest risks presented by the spruce beetles (Flint 2004). Less than $15 \%$ of respondents claimed that citizens in Kenai Peninsula communities had enough say in forest management. Common local sentiments about forest management of the spruce beetle outbreak included: (1) frustration over the lack of timber harvesting before timber value declined due to spruce beetle activity; (2) lack of coordination among land management agencies; (3) poor harvesting practices with damaging environmental consequences; and (4) not enough effort to reforest harvested areas. An alternative, strong environmental voice for letting nature run its course was heard by some segments of the population, particularly in Homer, Alaska (Flint 2007). When local sentiments ran counter to land management strategies, some communities mobilized considerable opposition and conflict, as found with Homer and Moose Pass, Alaska. Other communities appeared to lack sufficient levels of community participation and interaction to vigorously support or oppose forest management.

No two communities were alike in the full analysis of factors influencing local community action in response to the spruce bark beetle outbreak. The only factor that emerged as significant in all community level analyses regarding local action was interactional capacity, or the pre-existing capacity to work together on issues and threats regardless of the level of conflict (Flint and Haynes 2006; Flint and Luloff 2007). Some local communities had the capacity to mobilize collective local resources to offer considerable support and cooperation in mitigating forest risks, such as organizing neighborhood tree clearing for defensible space, participating in reforestation efforts, and supporting timber harvests on public lands. Other communities did not organize collectively, but individuals were working hard on their own properties to mitigate risks as much as possible, often at great expense. The study of Kenai Peninsula communities following forest disturbance by insects revealed a heterogeneous set of impacts and reactions across communities in a changing landscape over time.

\section{Mountain Pine Beetles in North Central Colorado}

In the time period from 1996 through 2007, mountain pine beetles (Dendroctonus ponderosae) affected more than $1,000,000$ acres (400,000 hectares) of lodgepole pine (Pinus contorta) and more than 500,000 acres $(200,000$ hectares) of Ponderosa pine (Pinus ponderosa) in Colorado. The outbreak continues to expand across the state with the heaviest impact in Eagle, Grand, Jackson, Routt, and Summit Counties (Hackett 2007). Affected communities range from the luxury resort communities of Vail and Breckenridge to the traditional "Old West" rural community of Walden in Jackson County (Winkler and others 2007). 
Preliminary findings from Colorado research highlight high levels of awareness and concern about the pine beetle issue across north central Colorado, despite dramatic differences in community characteristics (Flint 2008; Ganning and Flint 2008). Consistently, local residents remarked that the insect disturbance is a natural process exacerbated by management practices and climatic factors. Perceived negative impacts from the beetle outbreak included aesthetic and scenic loss, the high economic cost of mitigation attempts (such as spraying with insecticides and removing trees), and effects on the recreation and tourism orientation of the region. Concern about fire hazard was high. On the other hand, economic opportunities for those employed in jobs related to harvesting and processing trees related to the beetle activity and threat were seen as positive benefits, especially in communities with a timber harvesting tradition. Impacts from beetle activity were highly salient among community residents across north central Colorado, despite the fact that some communities are situated in open areas some distance away from forests. The nature of each community's amenity-based orientation affected its overall response to forest change and disturbance with more affluent, resort oriented community residents generally having higher levels of trust in federal forest management and less faith in forest industry than those in less affluent communities with fewer amenity attributes.

The mountain pine beetle outbreak catalyzed considerable interaction across the region, bringing together different stakeholders and government representatives to focus on management strategies and to lobby for allocation of resources (Flint 2008). Homeowner associations, citizens, and municipalities were actively involved in Community Wildfire Protection Plan efforts, and beetle task forces in Summit and Routt Counties involved coordination among local residents, municipal governments, county commissioners, and state and federal agency representatives. Local residents varied in their level of engagement on the bark beetle issue, often depending on the number of susceptible trees on their property, their affected view, and their predisposition for community involvement. In some communities, the beetle issue brought stakeholders and land managers together in new relationships and these interactions provided a catalytic environment for collective action beyond forest management issues. This was particularly true in Summit County, where invigorated community action branched out from forest issues to address affordable housing, alternative energy infrastructure, and economic development. In other communities, however, there was bitter resentment about what was perceived as decades of neglect to active forest management blamed on federal land management preference for environmental regulations. This led to profound distrust between local residents and forest managers.
A critical issue in Colorado centered on what to do with the salvage timber from fire and beetle mitigation efforts. Support for forest products industry varied across the region. Communities highly dependent on tourism and recreation were less likely to support large scale forest industry. There was more support for forest industry in counties with existing or past resource extraction orientations. There was cross-community support for small-scale forest products industry including niche markets (such as post and pole operations, furniture, and decorative wood panels) and biofuel energy production (though with some uncertainty about the community and environmental implications of timber-based biofuel generation).

The Colorado mountain pine beetle disturbance continues to unfold as beetle activity spreads across the mountainous region of the state. The US Forest Service has adopted a general approach of planning for "the next forest" (D. Carroll, USFS, personal communication, May 14, 2006) as foresters contend that little can be done about this particular forest disturbance by mountain pine beetles. However, many local stakeholders have shorter term values, management objectives, and needs tied to forests and there is little patience with allowing this disturbance to run its natural course (Flint 2008). Wildland-urban interface areas are particularly challenging for decision-making and forest management due to the intersecting disturbance dynamics such as fire, invasive plant species, and development which are related in a number of ways to the insect disturbance. Balancing the ecological, social, and economic changes and risks tied to disturbed forests presents challenges for regional ecosystem management and the well-being of local residents and communities in Colorado.

\section{Spruce Beetles in the Bavarian Forest National Park} in Germany

Over the past 20 years, Bavarian Forest National Park in southeast Germany has witnessed sustained spruce bark beetle (Ips typographus) activity due to beetle management restrictions on the park's territory. By 2007, the area of beetle-killed stands amounted to more almost 5500 ha or more than one-fifth of the park's total area. Different ecological conditions and the park's zoning policy resulted in an uneven spatial distribution of forest damage. The mountain vegetation zone above $1100 \mathrm{~m}$ in the southern part of the park was most severely affected with a tree mortality of over $90 \%$. Forest stands at lower altitudes and in the northern part of the park, in which spruce beetles are still controlled, suffered considerably less (see Heurich and others 2001).

In contrast to the three North American case studies, the epidemic nature of the Bavarian outbreak was the immediate consequence of a deliberate decision to prioritize 
nature conservation over forest management. Although the spruce bark beetle is endemic to spruce forests in Germany, it is usually kept in check through intensive management. Management of Bavarian Forest National Park, however, pursues the goal of 'letting nature follow its course' (Natur Natur sein lassen) (Rall 1998). Aiming to protect the forest against human interference, no management actions were implemented to control the spread of the spruce beetle.

The effects of the spruce beetle on the forest industry have been negligible. In contrast to the Canadian case (Patriquin and others 2007), the overall contribution of forestry to the regional economy is relatively low, even in this forest-rich region of Bavaria. Within the national park, logging is completely ruled out on about $55 \%$ of the area, whereas on the remaining $45 \%$ salvage logging of infested trees is carried out to prevent the spruce beetle from spreading.

There is greater concern about the effects of spruce beetle activity on tourism and visitation numbers (Suda 2003, 2006). In general, tourism plays a central role in the Bavarian Forest region. The number of overnight stays per inhabitant is four to five times the Bavarian average. Bavarian Forest National Park is also a popular holiday destination receiving more than 750.000 visitors per year. Areas with severe beetle damage coincide with the most popular tourism hotspots, exposing a significant number of visitors to the dead wood landscapes (Müller and Job 2008).

Studies have shown that visitors' affective responses to the unusual visual imagery of post-beetle landscapes are highly emotional: the barren landscape is associated with notions of decay and neglect and conjures up deeply ingrained images of forest dieback due to acid rain (Stelzig 1997). In a more cognitive assessment, however, visitors display a rather balanced attitude towards the spruce beetle. Studies suggest that the spruce beetle outbreak did not change visitors' satisfaction with their holiday experience and did not prompt them to stay away from Bavarian Forest National Park (Suda 2003). What is more, visitors even seem to be able to appreciate the protected area setting as an environment where the spruce beetle has a right to exist and reject controlling the beetle in the national park (Müller and Job 2008; Müller and others 2008). Findings of research with visitors also call for greater differentiation in assessing the perception of dead wood. While lying dead trees covered in visible green-up were interpreted as signs of wilderness unleashed, standing dead trees with little or no green-up were rejected as "unnatural" (Stelzig 1997).

A high population density of almost 90 people per square kilometer and the fact that over 150,000 people live within 30 kilometers of the park boundary suggest the salience of the social dimension of spruce bark beetle activity. In fact, the spruce beetle outbreak has stirred up communities like no other issue over the past 15 years. A survey of the regional and local press conveys an impression of the pre-eminence of the beetles issue in public life: in recent years the epidemics on average prompted one letter to the editor every two days. It is not, however, the biophysical risks which are felt most keenly by the local population; unlike the Alaska sentiments (Flint 2007), fires, biodiversity loss, erosion, and falling trees are of relatively low importance to Bavarian residents. As the communities around the national park are not primarily resourcedependent communities, they do not have a significant stake in the timber production.

More than anything else, the spruce beetle outbreak in the Bavarian Forest presents a political issue in the sense that it functions as a social force which reflects local power struggles and creates social boundaries and divisions. This is well illustrated by the way the spruce beetle mobilized local opposition to the national park. Historically, Germany has especially been plagued by resistance to the designation and management of national parks - a result of a complex web of reasons involving deficient communication as well as deeply ingrained emotional biases as central factors. Frequently, this kind of opposition derives from stereotyped relationships between nature conservation and other social and economic interests which are deeply rooted in social identities and connected to group processes (Stoll-Kleemann 2001). In the local communities around Bavarian Forest National Park, the spruce beetle has been closely tied to resistance to the national park (Rall 1998; Rentsch 1988). Somewhat similar to Colorado, the transformative effects of the spruce beetle on Bavarian forests galvanized social groups into action and created deep chasms between national park supporters and opponents, when in the mid-1990s plans were made public to enlarge the national park (Weiß 1998). In rallying around the spruce beetle, local action reduced the political discussion for and against the enlargement to the question of how to "correctly" deal with the spruce beetle. Attitudes toward the national park were projected through the spruce beetle, turning it into a political vehicle, which came to symbolize competing conceptions of nature and natural resource management in a public dispute (Rall 1998).

The lack of adequate participation of local residents in resource management decisions is widely acknowledged as the key reason for the emergence of negative attitudes towards the spruce beetle (Rall 1998; Weiß 1998). The Bavarian Forest has always been a critical means of existence for locals, and there is a long history of active forest management. The strong emotional attachment to the forest plays a key role in local identity narratives (Stallhofer 2000). The imposition of an external management, represented by the national park administration, and the exclusion from management decisions bred resentment 
among local landowners and community residents. This dismay was even amplified by what was perceived as a brutal neglect of the forest and forest resources by not controlling the spruce beetle. It was only after persistent protests following the enlargement of the national park that mechanisms for local participation and indeed a right to veto decisions were institutionalized.

What is more, communication of the purpose and aims of the national park was haphazard and inconsistent. When it was designated in 1970, the national park was presented and managed primarily as a tourist attraction to help promote regional development in this structurally laggard region. It started under the motto of "conserving the forest for our children and grandchildren" (Haug 1993). Following a change in the management philosophy in the 1980 s, protecting the integrity of ecological processes was preferred over conserving and actively managing the forest stands in the park. It was not anticipated by the national park management that this would result in the massive reproduction and spread of the spruce beetle. The local population felt betrayed by the national park management, which had both deviated from its original mission and failed to communicate what profound changes this would entail for the forest (Rall 1998).

\section{Lessons Learned and Implications}

Empirical research on the human dimensions of forest disturbances by insects reveals a more complicated set of impacts, risks, and issues than typically portrayed in the ecological and forestry oriented literature on disturbances. One-size-fits-all interpretations of the human dimensions of forest disturbances are likely to be myopic and incorrect, leading to problems and conflicts when forest management plans are based on homogeneous assumptions without adequate empirical evidence. A number of lessons can be learned from accreting the knowledge in this article gained through the four empirical studies of the human dimensions of forest disturbances by beetles.

\section{Multiple Impacts Require Multiple Strategies: \\ Economic Implications}

Forest disturbance impacts often include economic ramifications, but there are both positive and negative elements to these economic dynamics depending on one's perspective. Property values, impacts to recreation and tourism, and cost of mitigation efforts may or may not be strikingly negative impacts of major forest disturbance by beetles. The economic implications of increased fire hazard exacerbated by beetle activity can be substantial for individuals, communities, and the broader array of public land management entities and state and federal interests. But for those employed in or benefiting from active timber harvesting, mitigation efforts, and subsequent industrial and commercial activities, the economic impacts of forest disturbances by beetles can be positive at least in the short run.

Variation in the regional economic impact sensitivity to forestry export shocks, as found in British Columbia, supports the need for a tailored policy response. Model simulations suggest that a single policy approach will not address the economic needs of all forest-based communities affected by insect infestations. Some regions may require extensive mitigation policies such as re-training the workforce, government assistance, and regional economic initiatives.

The economic impacts and risks related to forest disturbance are often one of the most important factors affecting the livelihoods of local residents. Addressing potential economic impacts as early as possible is critical to long-term community well-being. Blending forest disturbance management plans with community and economic development efforts may be particularly beneficial by revealing labor needs and availability, marketing options, community acceptance of industrial responses, and other logistical barriers and opportunities.

Multiple Impacts Require Multiple Strategies:

Non-Economic Implications

While economic impacts tend to be the primary human dimension highlighted by management agencies, politicians, and the media, there are a variety of other impacts and risks of critical importance to communities affected by forest disturbances by insects. The impact of beetles on the aesthetics of forested landscapes can be profound, especially in homogeneous forest stands. The human response to this landscape change is often quite emotional with a dynamic grieving process often described as including the phases of denial, shock, anger, sadness, resignation, and moving on. For some, the renewal aspects of forest disturbance create a more positive emotional effect.

Given that communities differ in their socioeconomic, sociocultural, and biophysical characteristics (Luloff and others 2007), forest disturbances are likely to be met with different reactions and responses in different communities. Communities with luxury resorts or natural recreation or tourist amenities may be more concerned with aesthetic and economic changes. But even this assumption needs to be further disaggregated. Recreational interests vary from motorized to nonmotorized activities with different types of human-forest interactions and different values and demands regarding how forests and forest disturbances should be managed. Communities with resource extraction orientations or traditions may be more concerned with 
industrial responses to changing forest conditions and relationships with land managers. However, care should be taken not to assume that communities with economic interests tied to timber harvesting are not also concerned with risks to aesthetic quality. Generations of local residents are likely to have forest-based traditions, and local identities may depend upon the integrity of the forest just as much as in a high-profile alpine resort.

The complex array of attitudes and perspectives in local communities and among stakeholders with different interests can lead to considerable conflict from the neighbor-toneighbor scale over tree clearing to community versus public land management agency tension over forest management plans and beyond. Relationships between citizen stakeholders and land managers are complicated by varying levels of confidence and trust which have implications for risk perceptions and implementing management strategies (Earle and Siegrist 2006). Risk perceptions beyond concerns over economic costs of forest disturbances include threats to personal and property safety, threats to community identity tied to forested landscapes, and threats to general ecological well-being.

The western Canadian experience of forest disturbance by MPB revealed considerable variability in the impacts, vulnerability, and adaptability of communities affected by the infestation, and limits to the acceptability of forest insect disturbances in protected areas. A community level assessment of physical, social, and economic vulnerabilities can provide information about levels of exposure and adaptive ability that can lead to specific adaptive strategies, investments, and actions at the community level (Parkins and MacKendrick 2007). In western Canada, for example, several communities have formed coalitions to identify community strengths and vulnerabilities, to pool resources, build capacity, and provide a stronger united voice on MPB management and community issues. Adaptive strategies, however, should not only be focused on communities deemed to have biophysical or economic risk. As revealed in the western Canada and Colorado studies, communities distant from the outbreak or those not directly affected economically may also be impacted by the uncertainties surrounding infestation outcomes, leaving residents feeling vulnerable and affecting their trust in management agencies.

The case of Bavarian Forest National Park calls for an increased attentiveness specifically to the political effects of forest disturbance by insects. It urges to move beyond research on the human perception of risks to look at how forest disturbance restructures social life and affects local identities in communities. An understanding of how disturbance becomes socially constructed and mobilized in political conflicts about resource management provides hints on how to minimize the unsettling effects on communities. Candid communication among forest managers and stakeholders and bottom-up opportunities for participation in management decisions are key strategies to soften the opposition to crucial management decisions and incorporate stakeholders' expectations into management plans.

In areas of extensive recreational use, such as national parks, visitors need to be included in policy decision processes as an important stakeholder group, not least because tourism is a major source of regional income and detrimental effects on visitor experience can have immediate impacts on the regional economy. Studies show that visitors' attitudes towards the bark beetle may differ significantly from those of local residents. In particular, if educated about the bark beetle's function in ecosystems, visitors may be prepared to accept aesthetic downgrades if they are associated with the protection of ecological integrity.

The broad array of impacts articulated from local community and visitor perspectives suggests the importance of carefully assessing the human dimensions of forest disturbances for sound decision making and successful implementation of management strategies. Assumptions about any one impact or combination of impacts in all places may be incorrect. Another important consideration is that perceived impacts and risks change over time with the evolving cycle of ecological disturbance. Communication among resource managers, decision makers, local community residents, and regional stakeholders is central to managing this complex array of factors. Providing regular, comprehensive and candid information, both to residents and to tourists is essential. Downplaying the consequences of forest infestations are likely to backfire.

\section{Early Assessment of Community Conditions}

As a result of the complexities and variations in community responses, early assessment of community vulnerabilities and capacities related to forest change is essential. Background data on demographic and socio-economic conditions, levels of tourism and amenity orientation, financial dependence on forestry, existing community action-oriented institutions, and patterns of resource utilization can help to differentiate among a set of communities potentially threatened by forest insect disturbance. Collecting such information also supports longitudinal assessment which is particularly important as forest insect disturbances are dynamic over space and time. Based on background assessments of existing secondary information, social science research methods such as interviews, focus groups, and surveys allow for local voices and opinions to be heard. A mixed methodological approach to assessing local perspectives and conditions helps to address 
management and research questions from different directions, yielding more complete understanding.

\section{Tapping into Capacities for Local Action}

Tapping into local capacities for residents to act collectively can facilitate forest management and risk mitigation as well as support local community well-being. Strong local sentiments counter to resource management goals sometimes have the power to frustrate traditional forest management strategies when they feel their experience and sentiments are excluded from decision-making. The "art of listening" (Fitchen 1990), cultivated early in the forest decisionmaking and management process, supports collaboration with local communities for mutual benefit. Some communities may possess strong sentiments among residents but lack the capacity to mobilize local action. In these cases, it would be wrong to assume that a lack of action suggests apathy regarding forest management objectives. Efforts to facilitate community participation can foster helpful collaboration from private landowners and community residents. Local participation should start as early as possible, not after the most important decisions for managing disturbances have already been made. Management agencies should not underestimate the time required to negotiate a management strategy with local stakeholders.

Enabling participation through committees and roundtable discussions can help to institute formal routines for letting communities have a say. It is important not to make the management process appear as if guided through some distant expert community or extra-local management guidelines. Instead, genuinely acknowledging and incorporating local sentiments is likely to go a long way to ameliorating frustrating conflicts.

If relations between local communities and land management entities or agencies are strained, a neutral-party approach may be helpful. As the experiences from Western Canada, Alaska, Colorado, and Bavaria indicate, local community residents may not deem land management agencies as entirely trustworthy. National Park or Forest Service managers and agents are sometimes seen as biased and may not be easily accepted as mediating institutions. It may be helpful to create a separate, impartial program/ management center or task force to facilitate forest disturbance management and communication among multiple land management agencies and stakeholders and to empower local residents to get involved.

\section{Conclusion}

Complex environmental issues and their intersection with public interests and conflictual local human dimensions are often referred to as "wicked" or "messy" problems (Lachapelle and others 2003). Yet, resource managers will hopefully not succumb to the temptation to give up, saying these are unsolvable problems. Solutions to these complex natural resource problems come in the process of interacting with multiple interests and stakeholders-not in particular outcomes. It is important to resist the temptation to seek only those strategies for which consensus can be reached. Given the competing array of interests and issues, doing so may push aside critical issues that need dialogue and time to sort out even if consensus cannot be reached.

Resource management strategies in the face of forest disturbance by insects (and indeed other kinds of disturbances) should be adaptable to local contexts in order to accommodate variations in human dimensions across landscapes as well as the biophysical parameters of forest disturbances. They also need to be flexible enough to respond to changing variables as the cascading and changing nature of ecological disturbances is often related to changing human and community reactions and responses.

The Canadian and Colorado experiences with mountain pine beetles and the Alaskan and Bavarian experiences with spruce bark beetles outlined in this article illustrate the importance of including local human dimensions into assessments and management of forest disturbance by beetles. Forest disturbances have profound economic, social, political, and ecological implications for people living, working, and recreating in and near forest landscapes. The values, interests, and concerns of local stakeholders should be incorporated into management strategies to avoid costly conflicts and to reduce the long-term impacts of forest disturbances by insects.

Hopefully, this synthesis of forest disturbance experiences from various international contexts contributes to a growing dialogue with relevance for environmental policy and management. Drawing on wider regional, national, and international experience promotes adaptive learning and may lessen the shock and frustration for those facing and managing forest insect disturbances. Sharing experiences, as well as successful and failed management strategies, is critical not only for forest managers, but also for local residents and communities as well.

Acknowledgments The authors would like to thank the USDA Forest Service (Pacific Northwest Research Station), Natural Resources Canada, Parks Canada Agency, and Bavarian Forest National Park for supporting this research. An earlier version of this article was presented by the first author at the Louisiana Natural Resources Symposium in Baton Rouge, Louisiana in August 2007.

\section{References}

Berg EE, Henry JD, Fastie CL, DeVolder AD, Matsuoka SM (2006) Spruce beetle outbreaks on the Kenai Peninsula, Alaska, and 
Kluane National Park and Reserve, Yukon Territory: relationship to summer temperatures and regional differences in disturbance regimes. Forest Ecology and Management 227:219-232

British Columbia Ministry of Forests and Range (2006) The state of British Columbia's forests 2006. British Columbia Ministry of Forests and Range. Victoria, BC. Accessed 31 March 2008 http://www.for.gov.bc.ca/hfp/sof/

British Columbia Ministry of Forests and Range (2007) Timber supply and the Mountain Pine Beetle Infestation in British Columbia 2007 update. British Columbia Ministry of Forests and Range, Victoria, BC. Accessed 5 December 2007. http://www.for.gov.bc.ca/hfp/mountain_pine_beetle/\#whatsnew

Dale VH, Joyce LA, McNulty S, Neilson RP, Ayres MP, Flannigan MD, Hanson PJ, Irland LC, Lugo AE, Peterson CJ, Simberloff D, Swanson FJ, Stocks BJ, Wotton M (2001) Climate change and forest disturbance. BioScience 51:723-734

Daniel TC, Orland B, Hetherington J, Paschke JL (1991) Public perception and attitudes regarding spruce bark beetle damage to forest resources on the Chugach National Forest, Alaska. Final Report prepared for US. Forest Service Forest Pest Management, Anchorage, Alaska

Drever CR, Peterson G, Messier C, Bergeron Y, Flannigan M (2006) Can forest management based on natural disturbances maintain ecological resilience? Canadian Journal of Forest Resources 36:2285-2299

Earle TC, Siegrist M (2006) Morality information, performance information, and the distinction between trust and confidence. Journal of Applied Social Psychology 36(2):383-416

Fitchen JM (1990) How do you know what to ask if you haven't listened first? Using anthropological methods to prepare for survey research. The Rural Sociologist. Spring 10(2):15-22

Flint CG (2006) Community perspectives on spruce beetle impacts on the Kenai Peninsula, Alaska. Forest Ecology and Management 227(3):207-218

Flint CG (2007) Changing forest disturbance regimes and risk perceptions in Homer, Alaska. Risk Analysis 27:1597-1608

Flint CG (2008) Community perspectives on pine beetle impacts and management in Colorado. Paper presented at the Western forest insect working conference, Boulder, Colorado, April 8, 2008

Flint CG, Haynes R (2006) Managing forest disturbances and community response: lessons from the Kenai Peninsula, Alaska. Journal of Forestry 104(3):269-275

Flint CG, Luloff AE (2005) Natural resource-based communities, risk, and disaster: an intersection of theories. Society and Natural Resources 18(5):671-685

Flint CG, Luloff AE (2007) Community activeness in response to forest disturbance in Alaska. Society and Natural Resources. 20(5):431-450

Ganning J, Flint CG (2008) A context-based amenity index for select Colorado communities. Unpublished manuscript available from the authors

Gardner RH, Turner MG, O'Neill RG (2001) Landscape ecology in theory and practice: pattern and process. Springer, New York, $404 \mathrm{pp}$

Greider T, Garkovich L (1994) Landscapes: the social construction of nature and the environment. Rural Sociology 59(1):1-24

Hackett J (2007) Colorado's mountain pine beetle infestation offers important lessons about managing future forests. Colorado Conservator 23(2):8-9

Haug M (1993) Entstehungsgeschichte des Nationalparks Bayerischer Wald und Entwicklung seit 1969 [A history of the foundation of Bavarian Forest National Park and its development since 1969]. In: Bayerisches Staatsministerium für Ernährung, Landwirtschaft und Forsten (eds) Eine Landschaft wird Nationalpark [A landscape turns into a national park]. Morsak-Verlag, Grafenau, pp 35-84
Heurich M, Reinelt A, Fahse L (2001) Die Buchdruckermassenvermehrung im Nationalpark Bayerischer Wald [Mass reproduction of Ips typographus in Bavarian Forest National Park]. In: Nationalparkverwaltung Bayerischer Wald (ed) Waldentwicklung im Bergwald nach Windwurf und Borkenkäferbefall [Development of mountain forests after windthrow and bark beetle infestation]. Nationalpark Bayerischer Wald, Grafenau, pp 9-48

Irwin A (2001) Sociology and the environment. Polity Press, Cambridge, United Kingdom, 224 pp

Kasperson RE, Renn O, Slovic P, Brown HS, Emel J, Goble R, Kasperson JX, Ratick S (1988) The social amplification of risk: a conceptual framework. Risk Analysis 8(2):177-187

Kruse J, Pelz R (1991) Developing a public consensus on the management of spruce beetles on the Kenai Peninsula. Institute Soc. Econ. Res., University of Alaska, Anchorage, 36 pp

Lachapelle PR, McCool SF, Patterson ME (2003) Barriers to effective natural resource planning in a "messy" world. Society and Natural Resources 16(6):473-490

Luloff AE, Field DR, Krannich RS, Flint C (2007) A matrix approach for understanding humans, fire, and forests. In: Daniels TC, Carroll MS, Mosely C, Raish C (eds) People, fire, and forests: a synthesis of wildfire social science. Oregon State University Press, Corvallis, OR, pp 207-215

McFarlane BL, Watson DO (2008) Perceptions of ecological risk associated with mountain pine beetle (Dendroctonus ponderosae) infestations in Banff and Kootenay National Parks of Canada. Risk Analysis 28:203-212

McFarlane BL, Stumpf-Allen RCG, Watson DO (2006) Public perceptions of natural disturbance in Canada's national parks: the case of the mountain pine beetle (Dendroctonus ponderosae Hopkins). Biological Conservation 130:340-348

Molnar JJ, Schelhas J, Holeski C (2007) Nonindustrial private forest landowners and the southern pine beetle: factors affecting monitoring, preventing, and controlling infestations. Journal of Forestry 31(2):93-98

Müller M, Job H (2008) How to manage natural disturbance in protected areas? Visitors' attitudes towards the bark beetle in a German national park. Working Paper

Müller M, Mayer M, Job H (2008) Totholz und Borkenkäfer im Nationalpark Bayerischer Wald aus touristischer Perspektive [A tourist perspective on dead wood and bark beetles in Bavarian Forest National Park]. In Job H (ed) Die Destination Nationalpark Bayerischer Wald als regionaler Wirtschaftsfaktor [The significance of Bavarian Forest National Park for regional economic development]. Nationalpark Bayerischer Wald, Grafenau, pp 98-114

Oliver CD, Larson BC (1996) Forest stand dynamics. John Wiley and Sons, New York, $544 \mathrm{pp}$

Parkins JR, MacKendrick NA (2007) Assessing community vulnerability: a study of the mountain pine beetle outbreak in British Columbia, Canada. Global Environmental Change 17:460-471

Parks Canada (2003) What is ecological integrity? http://www.pc.gc. ca/progs/np-pn/eco_integ/index_e.asp. Accessed 5 December 2007

Patriquin MN, Wellstead AM, White WA (2007) Beetles, trees, and people: regional economic impact sensitivity and policy considerations related to the mountain pine beetle infestation in British Columbia, Canada. Forest Policy and Economics 9:938-946

Pickett STA, Cadenasso ML (1995) Landscape ecology: spatial heterogeneity in ecological systems. Science 269(5222):331-334

Rall H (1998) Zur Akzeptanz von Totalreservaten in der Öffentlichkeit: Erfahrungen aus dem Nationalpark Bayerischer Wald [On the public acceptance of total reserves: experiences from Bavarian Forest National Park]. http://www.waldwildnis.de/cd/ archiv/rall/h_rall.htm. Accessed 29 December 2007 
Rentsch G (1988) Die Akzeptanz eines Schutzgebiets untersucht am Beispiel der Einstellung der lokalen Bevölkerung zum Nationalpark Bayerischer Wald [The acceptance of protected areas: the case of residents' attitudes towards Bavarian Forest National Park]. Michael Laßleben, Munich, 87 pp

Rogers P (1996) Disturbance ecology and forest management: a review of the literature general technical report. INT-GTR-336. U.S. Department of Agriculture, Forest Service, Intermountain Research Station, Ogden, UT

Rosenberger RS, Smith EL (1997) Nonmarket economic impacts of forest insect pests: a literature review. General technical report. PSW-GTR-164. U.S. Department of Agriculture, Forest Service, Pacific Southwest Research Station, Albany, CA

Ross DW, Daterman GE, Boughton JL, Quigley TM (2001) Forest health restoration in South-Central Alaska: a problem analysis. General technical report. PNW-GTR-523. Department of Agriculture, Forest Service, Pacific Northwest Research Station, Portland, OR, US

Stallhofer B (2000) Grenzenloser Böhmerwald? Landschaftsnamen, Regionen und regionale Identitäten [Borderless Bohemian Forest? Place names, regions and regional identities]. Laßleben, Kallmünz, $250 \mathrm{pp}$

Stelzig I (1997) Akzeptanz von Totholz in ausgewählten deutschen Wald-Nationalparken [Acceptance of dead wood in selected German forest national parks]. Department of Biology, Frankfurt University, $112 \mathrm{pp}$

Stoll-Kleemann S (2001) Opposition to the designation of protected areas in Germany. Journal of Environmental Planning and Management 44:109-128

Suda M (2003) Die Zeit heilt alle Wunden: Wie Touristen sich an Totholzflächen gewöhnen [Time heals all wounds: how tourists get accustomed to dead wood]. LWF aktuell 40:28-30
Suda M (2006) Erholung zwischen toten Bäumen [Recreation among dead trees]. In: Guenther A, Hopfinger H, Kagelmann H-J, Kiefl $\mathrm{W}$ (eds) Tourismusforschung in Bayern [Tourism research in Bavaria]. Profil, Munich, pp 252-258

Taylor SW, Carroll AL (2004) Disturbance, forest age, and mountain pine beetle outbreak dynamics in BC: a historical perspective. In Shore TL, Brooks JE, Stone JE (eds) Mountain Pine Beetle symposium: challenges and solutions, october 30-31, 2003, Kelowna, BC. Information report BC-X-399. Natural Resources Canada, Canadian Forest Service, Pacific Forestry Centre, Victoria, BC, pp 41-51

Thomas WI (1928) The child in America: behavior problems and programs. Knopf, New York

Tilly C (1973) Do communities act? Sociological Inquiry 43(34):209-240

Weiß M (1998) Kaputtgeschützt? Zur Kontroverse um die Erweiterung des Nationalparks Bayerischer Wald [Protected to death? The controversy about the enlargement of Bavarian Forest National Park]. Geographische Rundschau 50:522-527

Werner RA, Holsten EA, Matsuoka SM, Burnside RE (2006) Spruce beetles and forest ecosystems in south-central Alaska: a review of 30 years of research. Forest Ecology and Management 227:195-206

Winkler R, Field DR, Luloff AE, Krannich RS, Williams T (2007) Social landscapes of the inter-mountain west: a comparison of "old west" and "new west" communities. Rural Sociology 72(3):478-501

Zimmerer KS (2000) The reworking of conservation geographies: nonequilibrium landscapes and nature-society hybrids. Annals of the Association of American Geographers 90:356-369 